Brit. J. industr. Med., 1959, 16, 181.

\title{
OCCUPATIONAL LUNG CANCER : A REVIEW
}

\author{
BY \\ RICHARD DOLL \\ From the Statistical Research Unit, Medical Research Council
}

(RECEIVED FOR PUbLICATION FEBRUARY 4, 1959)

Study of occupational factors was the method which led to the discovery of the first pure carcinogen. The study of such factors among patients with lung cancer has already been extremely fruitful and has led to the discovery of at least five, and possibly more, independent industrial risks. The carcinogenic factors concerned have not all been determined with certainty, but several of them appear to be simple inorganic compounds. The study of occupational factors also provides knowledge, difficult to obtain in any other way, of the biological relationship between exposure to carcinogens and the development of cancer in man and it is reasonable to hope that it will, in the future, make an important contribution to our knowledge of the fundamental mechanisms of carcinogenesis.

\section{Established Risks}

Radioactivity.-The first risk to be recognized was that run by the miners of Schneeberg and Jachymov. This is not of direct interest to us in Britain but it is of considerable indirect interest, as it provides one of the few sources of evidence from which we can assess the possible significance of the effect of exposure to ionizing radiations. The miners of Schneeberg and Jachymov had been known to suffer from a specific pulmonary disease for 500 years, but it was not until 1879 that the disease was recognized to be cancer. It is impossible now to be certain of the exact extent of the risk, but it is probable that $90 \%$ of the tumours causing death among the miners were bronchial in origin and that somewhere between $40 \%$ and $75 \%$ of all men who were continuously employed in the mines died of the disease. The best estimate of the risk is that approximately $1 \%$ of the miners were affected annually; this would mean that the risk must have been about 10 times greater than the large risk to which the general population of Great Britain is now exposed. Full data may be found in the reviews by Lorenz (1944) and Šikl (1950).

The mines have been worked successively for silver, nickel, cobalt, bismuth, arsenic, radium, and uranium. The characteristic which most sharply distinguished them from other mines was the high radioactivity of the ore and it may be noted that these mines provided the ore from which, in 1898, the Curies isolated radium. The first time a suggestion that the disease might be due to radioactivity appeared in the medical literature was in 1921 when Margarete Uhlig, herself a native of Schneeberg, commented that she had seen the suggestion "in an article by a layman". An average value for the concentration of radon in the air of the mines was found to be $3 \times 10^{-9}$ curies per litre (Evans and Goodman, 1940), but the measurements were made at a time when the ventilation had been improved and the previous values may have been substantially higher.

The dose of radiation received by the lungs would have been due more to the short-lived daughter products of radon carried on ore dust particles than to the radon itself, and the nature and amount of the atmospheric dust would have been of great significance in determining the quantity of radioactive substances inhaled and the site of their deposition. Bale and Shapiro (1955) calculated that with normal dusty air a concentration of $3 \times 10^{-9}$ curies of radon per litre would result in the tracheal epithelium receiving an average dose of about $\mathbf{0} \cdot \mathbf{2}$ rad per day. Owing to selective deposition the local dose might be more than 10 times the average, so that the miners who died of the disease may have received local doses of $10,000 \mathrm{rad}$ of $\alpha$-rays (Glucksmann, Lamerton, and Mayneord, 1957).

Experiments have shown that true squamous tumours can be produced in the bronchi of rats by radioactive cerium and by plutonium (Lisco and Finkel, 1949; Lisco, personal communication) and similar tumours have been elicited by bead implants of radioactive strontium, by single intratracheal injections of radioactive cerium, and by repeated injections of radioactive sulphur (Cember, 1958). The dose received locally in the lungs of the Schneeberg miners is calculated to have been of the same order as that received in the vicinity of the bone sarcomas which developed in the girls who ingested 
radium and there is no reason to doubt that radioactivity was the cause of the lesion. It may, however, have been assisted by other factors. In animal experiments, cancer has been induced by radiation more easily when non-specific inflammation was also present (Burrows and Clarkson, 1943) and silicosis was rife among the miners. Silicosis was, however, not particularly severe in those lungs in which cancer also developed.

No other groups of workers have been shown to have suffered a high incidence of bronchial tumours as a result of exposure to high doses of radioactivity. Many cases are believed to have occurred among the workers at the Shinkolobwe mines in the Belgian Congo, but no data have been published. At Port Radium in Canada, the miners have been highly mobile and no epidemiological evidence is available. Some evidence may eventually be obtained about the miners of the Colorado Plateau. Several of the mines in this part of the U.S.A. have had atmospheric radioactivity comparable to that at Schneeberg (Holaday, 1955), and an attempt is now being made to trace the effect on the workers. At most other uranium mines the ores have been of much lower grade and the existence of a risk would be difficult to detect. Whether exposure to the smaller doses of radioactivity in the normal environment is likely to produce any cases of the disease is unknown. If the incidence of cancer is proportional to the dose of radiation received it must be supposed that some few cases are likely to be due to this cause. The Londoner is exposed to about one ten-thousandth of the radioactivity that was present in the air of the Schneeberg mines and it would, therefore, appear that less than $1 \%$ of cases could be due to radioactivity. It may be, however, that small doses of this order are entirely free from risk and that no cases at all are produced. In the present state of knowledge it is impossible to give a tolerance level for radon with confidence: the official level is $10^{-11}$ curies per litre, but the only sensible attitude to take is that if workers have to be exposed to levels of radioactivity above those normally occurring, these levels should be kept to the minimum possible.

Nickel.-The only form of occupational lung cancer to have been prescribed as an occupational disease in Great Britain is that which occurs among men exposed to nickel powder formed "by decomposition of a gaseous nickel compound". It is, therefore, regarded as an occupational disease among the men employed at a large refinery in South Wales, where the nickel carbonyl process of refining is used. The first cases were reported by Amor (1939); since then many other cases have been reported and it is now known that at least 131 cases of lung cancer and 62 cases of nasal cancer have occurred among the men employed at this particular refinery in the last 35 years (Doll, 1958; Morgan, 1958). Cancer of the nasal cavities is normally such a rare disease that the occurrence of so many cases in the period is convincing evidence of the existence of a specific industrial hazard. It is, however, a different matter with regard to cancer of the lung. This disease has become so common that it is necessary to make a detailed assessment of the number of cases to be expected in the absence of a special hazard, before it can be concluded that the observed number is excessive.

Hill (1939) obtained data for the numbers and age distribution of the men employed by the Company, or on the Company's books as pensioners, for the years 1931 and 1937. Little change occurred between these years and he concluded that the average population for the two years provided a reasonable estimate of the population at risk for the period 1929-35. During this period, 16 deaths were attributed to cancer of the lung and 11 to cancer of the nose, whereas he estimated that the number expected from the experience of all England and Wales would have been 1 and between 0 and 1 respectively. In contrast, the numbers of deaths from other forms of cancer and from other causes were close to the expected numbers. Division of the men into two broad categories, depending on whether or not they were employed on any of the specific processes, showed that the whole excess was concentrated on the process workers, although these constituted little more than half the total number of employees. Doll (1958) has studied the data for a later period by an indirect method. From the records of the local medical officers of health he found that 48 out of 200 deaths reported among nickel workers during the period 1948-56 were attributed to cancer of the lung, i.e., $24.0 \%$, and a further 13 were attributed to cancer of the nose, $6.5 \%$. It was estimated that even in this period the risk of dying of lung cancer was nearly five times the high nonindustrial risk and that the risk of nasal cancer was 150 times the "normal" risk. These values were calculated for all grades of workers; for men described as process workers they were higher. But although the mortality among the workers remains high it seems probable that the hazard in the industry has now been greatly reduced, if not eliminated. According to Morgan (1958), four deaths from lung cancer would have been expected to occur among men who started employment at the works after 1924; only six have occurred, and, perhaps more significantly, none of the post-1924 workers has developed cancer of the nose. 
Despite the sudden change in the extent of the hazard, it is not possible to define the carcinogen with certainty. From Morgan's data, it is clear that the men who ran the greatest risk were engaged in calcining the original matter or in the extraction of the calcine with sulphuric acid. In contrast, relatively few cases occurred among the men who were principally employed in the sheds where the nickel was volatilized and decomposed. Five cases of lung cancer have, moreover, now been reported from a small Norwegian nickel refinery using an electrolytic process (Løken, 1950; Goldblatt and Goldblatt, 1956) and there is no reason to believe that the risk is confined to the use of the nickel-carbonyl process. The only obvious change which took place in the period 1920-24 was the substitution of an almost arsenic-free sulphuric acid for an acid containing large amounts of arsenic and Morgan has, therefore, suggested that arsenic may have been the responsible factor. This is not very likely, however, as even large amounts of arsenic in the atmosphere of another factory have not produced the same high risk of lung cancer and they have produced no cases of cancer of the nose (see subsequent section). Large quantities of dust used to be produced in the early stages of the process and it seems most likely that the agent was present in the original raw material, which contained nickel and copper in almost equal amounts. Nickel, in powdered form, has been shown to be capable of producing sarcoma in rats by both intrafemoral and subcutaneous injection (Hueper, 1955) and it has also produced adenomatoid changes in the lungs of rats and guinea-pigs when the animals were exposed to it in the atmosphere for prolonged periods (Hueper, 1958a).

Chromates.-The suggestion that there might be a risk of lung cancer from the manufacture of chromates was first made in Germany in the early 1930s (Pfeil, 1935; Alwens, Bauke, and Jonas, 1936). By 1950, Baetjer was able to find records of 62 German cases, but the population at risk was not known with accuracy and it was impossible to be sure of the existence of a specific hazard until Machle and Gregorius (1948) and Brinton, Frasier, and Koven (1952) analysed the mortality for workers at seven chromate plants in the U.S.A. Of 193 deaths, $42(22 \%)$ were attributed to lung cancer and this was estimated to be about 30 times the number which would have been expected from the national mortality data or the records available for other industrial workers. In contrast, the mortality from other types of cancer was about normal. At first it was thought that no similar risk occurred in Britain and the difference between the experiences in the two countries was tentatively attributed to differences in the treatment of the waste ore. Subsequently, however, Bidstrup and Case (1956) recorded the deaths among 724 male chromate workers in these British factories and, in a five-year period, found that 12 out of $59(20 \%)$ were due to cancer of the lung. This, they estimated, was about three and a half times as many as would have been expected in the absence of a specific risk. It is clear, therefore, that an appreciable risk does occur in Britain and it is interesting to note that a risk of this order can be entirely overlooked by both the management and the workers concerned. Whether the risk is appreciably different from that which has been incurred in the U.S.A. is not clear. At first sight, it might be thought that the American risk was greater since it was reported as being about 30 times "normal", whereas the British risk was reported as being three and a half times "normal". There is, however, a fallacy in this comparison. The disease was many times commoner among the general population of Britain in the 1950s than among the general population of the U.S.A. in the 1930s and the two "normals" were entirely different. In fact, the proportions of the total deaths which can be attributed to industrial lung cancer are not very different, i.e., $21 \%$ in the U.S.A. and $15 \%$ in Britain.

The pure carcinogenic agent has not yet been isolated. Schinz and Uehlinger (1942) produced cancers in two animals by the injection of chemical chromium intrafemorally and this may, perhaps, suggest that the metal itself is responsible. More recently, Hueper (1958b) has obtained sarcomas in rats by the implantation of either chromite ore roast or of sintered calcium chromate. Several cases have been recorded in Germany among workers manufacturing chrome pigments from dichromates (Gross and Kölsch, 1943), but Machle and Gregorius (1948) found no lung cancer deaths at the one American plant where the only important exposure was to dichromates and chromic acid. It may be recalled also that whereas exposure to dichromates frequently gives rise to ulcers of the skin and nasal septum, these ulcers do not undergo neoplastic change. It seems probable that the agent is found in the primary ore, and Mancuso and Hueper (1951) are of the opinion that it is likely to be trivalent chromium in the form of an acid-soluble-water-insoluble compound.*

* Further studies by Hueper and Payne (personal communication) have shown that it is possible to induce sarcoma in a high proportion of rats by intrafemoral or intrapleural injections of (1) calcium chromate, (2) sintered calcium chromate, or (3) sintered chromium trioxide. These observations indicate that chromium itself is a carcinogenic agent. No effect was produced by barium chromate, and Hueper and Payne suggest that the biological effect is dependent on the solubility of the compound, subject to the amount being insufficient to cause cell necrosis. 
Asbestos.-The first case of cancer of the lung in association with asbestosis was reported by Lynch and Smith (1935) in the U.S.A. Since then about 80 to 100 cases have been reported from Britain, Canada, Germany, and the U.S.A.- the greatest number from Britain. Some authors are impressed by the paucity of the numbers more than by their frequency (Bohlig and Jacob, 1958; Braun and Truan, 1958) but many cases have not been reported. The first indication that the association was not coincidental was obtained by Merewether (1949), who found that lung cancer was reported at necropsy more frequently among asbestotics than among silicotics and this was confirmed by Gloyne (1951) who, in a personal series, found lung cancer in $14.1 \%$ of persons dying with asbestosis (17 out of 121 ), against $6.9 \%$ among persons dying with silicosis (55 out of 786). Since the prevalence was higher in men $(19.6 \%$ among the male asbestotics in Gloyne's series) and since the proportion of men is likely to have been lower among asbestotics than silicotics, the contrast between subjects of the same sex would probably have been greater than that reported for both sexes together. The data have been criticized on the grounds that the material was selected and was not representative of all persons exposed respectively to asbestos and silica dust. There is, however, no reason to suppose that the criteria by which cases were referred to Gloyne differed in respect of the two types of pneumoconiosis.

Only two direct studies of the mortality among men exposed to asbestos have so far been reported. Braun and Truan (1958) observed the mortality among 5,958 Canadian asbestos miners over a sixyear period and found nine deaths "proved" to be due to lung cancer and three in which the diagnosis was "suspected". They concluded that if the mortality had been similar to that recorded for the whole Province there would have been eight lung cancer deaths and they concluded that "the asbestos miners in the Province of Quebec do not have a significantly higher death rate from lung cancer than do comparable segments of the general population". In contrast, Doll (1955) found a very high lung cancer mortality among 113 men who had been employed for $\mathbf{2 0}$ or more years in parts of a British asbestos factory where they were likely to have been exposed to asbestos dust. The men were followed from the time of completing their 20 years' service until the end of 1954, that is, for an average of just over nine years. In this period there were altogether 39 deaths, including 11 attributed to lung cancer; the numbers of deaths expected from the agespecific national morbidity rates were respectively 15 and one. The incidence of lung cancer was found to be highest among the men who had had the longest exposure to the conditions existing before the 1931 "Asbestos Regulations" were made effective and it decreased progressively as the duration of such exposure was reduced.

These two sets of observations are not necessarily contradictory. The explanation may, perhaps, be found in a difference between the environmental conditions. Neither the size not the chemical constitution of the dust particles are likely to have been the same (chrysotile in the first study and a mixture of chrysotile and hornblende in the second) and it may be noted that asbestosis was believed to be present in under half of the Canadian cases (five out of 12), whereas it was present in all the British cases. It seems reasonable to conclude that exposure to asbestos dust does give rise to lung cancer, but that the circumstances in which it will do so have not yet been fully defined.

The fibrils of asbestos consist of giant molecules of polymerized silico-oxygen tetrahedra arranged in chains or bands. In Canadian asbestos, the silica is present as hydrated magnesium silicate containing $6 \%$ of iron oxide; in other, industrially less important types, the silicates may be calcium and magnesium or sodium and iron. In Hueper's view (1957) the carcinogenic activity may result from the physical form of the material as a linear polymer and the mechanism may be similar to that by which cancer has been induced in animals with various polymerized carbon compounds. Alternative views are discussed by Goldblatt (1958). Animal experiments with asbestos itself have so far been negative.

Gas Production.-The combustion and distillation products of coal provide a rich source of carcinogens and they have long been recognized as capable of producing cancer of the skin among men who come into close contact with them in the course of their work. It would, therefore, not be surprising if the fumes and dust from coal tar were capable of giving rise to cancer of the lung. Evidence that this might be so has been obtained in three countries. In Japan, between 1931 and 1937, 21 cases of lung cancer were diagnosed among gas generator workers and ex-workers of the Yawata steel works and there can be no reasonable doubt that this indicates an abnormal incidence (Kuroda and Kawahata, 1936; Kuroda, 1937; Kawahata, 1938). Lung cancer was-and still is-a rare disease in Japan and no deaths were attributed to lung cancer among the other employees at the works during a period when 12 such deaths occurred among the gas workers. In contrast, the mortality from other types of cancer was of the same order among both groups of employees, that is, three deaths among approxi- 
mately 500 gasworkers and 49 deaths among approximately 19,000 other workers. It follows that among the gasworkers lung cancer accounted for $80 \%$ of all the cancer deaths, i.e., 12 out of 15 . The men worked directly above the ovens and, when the coal was stirred, yellow-brown gas streamed directly over them.

In Canada, Sutherland (personal communication) found that the lung cancer mortality among men who worked in the retort house of one Canadian gasworks was 15 times greater than that recorded for the general population of the district; among these workers 19 deaths were attributed to cancer and the primary site was recorded as being in the respiratory system in nine, i.e., in $47 \%$. The retorts used were of the horizontal type and the men who operated them were exposed from time to time to quantities of hot fumes. Employees who had never been employed in the retort house showed no excess mortality from respiratory cancer and neither did the employees at another works, where the retorts had long been changed to a more modern type. In Britain, Kennaway and Kennaway (1936 and 1947) analysed the occupations of men certified as dying of lung cancer between 1921 and 1938. Four out of the five occupations with the highest mortality had special exposure to the fumes (labourers at "patent fuel" works, gas stokers and coke oven chargers, gas producer men and gas works foremen and inspectors). Among men employed in these occupations the expected number of deaths from lung cancer was 51 and the observed number was two and a half times as great, i.e., 125. A slightly lower ratio was found some years later in a study of 2,071 male pensioners of a large London gas company (Doll, 1952). Twenty-five deaths were attributed to lung cancer and the expected number, at the rates recorded for all male Londoners of the same ages, was 14. The excess is small, but the investigation covered a multiplicity of occupations and the risk may have been substantially greater for those men who were directly concerned with the production process. Reid and Buck (1956), on the other hand, were unable to find any evidence of an increased risk among men employed in the production of metallurgical coke. With the passage of time and the increase in the mortality experienced by the nonindustrial population, it becomes progressively more difficult to recognize a specific industrial hazard and it will require a detailed investigation over many years before it is possible to say whether or not there is any risk involved in the operation of the modern type of retort. Such an investigation has been started under the auspices of the Medical Research Council, but it may be several years before a decisive result is obtained.
Quantitative estimates of the amount of carcinogen likely to be inspired are not as yet available. Measurements at one works where vertical retorts were employed showed that the amount of 3:4-benzpyrene in the air might be five to 10 times more than in the general atmosphere of a large English town (Hughes and Somerville, personal communication). If it were possible to link this pollution with a particular incidence of the disease, it might be of great help in assessing the risk associated with "normal" urban smoke.

\section{Suspected Risks}

Arsenic.-That arsenic is capable of causing cancer in man is demonstrated by the occurrence of cancer of the skin among patients who had received arsenic by mouth and among men who were exposed to arsenical dust in the course of their work. The latter group are known also to be subject to ulceration of the nasal septum. It is, therefore, not surprising that arsenic has long been suspected to be a cause of cancer of the lung. Arsenic was present in small amounts in the ore of the Schneeberg and Jachymov mines and in the raw materials used by the nickel refiners of South Wales and in both instances it has, at times, been regarded as the effective carcinogen. In fact, the evidence to implicate arsenic is slight. Four cases of lung cancer among sheep dip workers were notified to the Ministry of Labour between 1939 and 1943 (Merewether, 1944) and one case occurred in a man who made a sodium arsenite insecticide and had a heavily pigmented skin, numerous warts, and a perforated nasal septum (Bridge, 1941).

The only direct evidence was obtained by Hill and Faning (1948), who analysed the cause of death among the employees of a small English factory in which arsenical powders were prepared from sodium arsenite. Examination of the death entries in the offices of the local registrars of deaths provided records of 75 deaths among male employees between 1910 and 1943. The causes of death were compared with the causes recorded for other male manual workers resident in the same area during the same period and it was found that the proportion attributable to cancer was higher for the factory workers $(29.3 \%)$ than for the other workers $(12.9 \%)$; moreover, it was higher still among the chemical workers who were most likely to come into direct contact with the arsenical dust $(39.0 \%)$. The high proportion of cancer deaths was largely due to an excess of deaths from cancer in two sites. Out of 22 cancer deaths, three were attributed to cancer of the skin and seven were attributed to cancer of the respiratory system (lung five, mediastinum one, larynx one) against expected numbers estimated to be 0.1 and 
1.0 respectively. Environmental studies, carried out at the same time, showed that very large amounts of arsenic might be present in the air, ranging - at mouth height in one part of the factory-from $310 \mu \mathrm{g}$. per m. ${ }^{3}$ to over $4,000 \mu \mathrm{g}$. with a mean of about 1,000 $\mu$ g. (Perry, Bowler, Buckell, Druett, and Schilling, 1948). Large amounts of arsenic were found in the urine and hair of the workers and the majority of the chemical workers were grossly pigmented; approximately one-third had warts.

It seems probable, therefore, that exposure to inorganic arsenic in the air may produce lung cancer, if the amount present is sufficient to produce gross evidence of arsenicism. In the absence of such evidence, it seems most unlikely that the amount of arsenic inspired could be sufficient to account for any important industrial risk of the disease.

Iron.-The siderosis caused by pulmonary retention of $\mathrm{Fe}_{2} \mathrm{O}_{3}$ or $\mathrm{Fe}_{3} \mathrm{O}_{4} \cdot \mathrm{H}_{2} \mathrm{O}$ is usually considered to be innocuous, but there is some evidence to suggest that it may lead to an increased risk of lung cancer-particularly when it is associated with silicosis. The most detailed data have been obtained by Faulds and Stewart (1956) in relation to haematite miners. Haematite consists principally of ferric oxide, but it also contains 10 to $12 \%$ of silica. It has been mined in Cumberland since Roman times, but the introduction of new drills, just before the first world war, greatly increased the dustiness of the work and effective measures for the suppression of dust were not taken for over 20 years. Faulds and Stewart found that among the miners (1) the prevalence of lung cancer at necropsy increased sharply from $4.4 \%$ in 1932-47 (four in 92 necropsies) to $14.6 \%$ in $1948-53$ (13 in 89 necropsies); (2) the prevalence was greater than among other Cumberland males of approximately the same age distribution, i.e., $9.4 \%$ (17 in 180 necropsies) against $2.0 \%$ (45 in 2,221 necropsies); and (3) at least six growths appeared to have arisen from sidero-silicotic masses. Such evidence is, however, not conclusive. The prevalence of lung cancer increased sharply throughout England during the same period and it is impossible to be sure that the incidence among the miners as a whole was really higher than normal. Necropsy data of this type are difficult to interpret, because subjects who come to necropsy may not be representative of the population from which they are drawn. Even in the period since 1948 only $56 \%$ of the miners who died came to necropsy. Compensation is payable if death is attributed to silicosis and those who came to necropsy must be presumed to include the great majority of the miners dying with pulmonary symptoms. The true incidence may, therefore, have been as low as 13 cases among
160 miners and this figure $(8.1 \%)$ is not very different from that which would have been expected from the national mortality data. Among other Cumberland males, on the other hand, the reasons for which a necropsy is performed are presumably, different. The most important reason is likely to be sudden death, so that the proportion of necropsy cases coming, in which there is evidence of lung cancer, may be below the average for the population as a whole.

A moderately high mortality has been reported among several other groups of iron workers. Turner and Grace (1938) found that foundry workers, smiths, and metal grinders had a mortality from lung cancer higher than that for any other occupational group in Sheffield and metal grinders were also found to have suffered an excessive mortality from lung cancer in Kennaway and Kennaway's (1947) study of the deaths certified as being due to lung cancer in the whole of England and Wales. In the period 1921 to 1938 they found 39 deaths recorded among metal grinders, whereas they estimated that the expected number was $22 \cdot 2$. The ratio of the observed and expected number of deaths $(1 \cdot 76$ to 1$)$ was exceeded only by three groups of gas or pitch workers out of the 56 occupational groups examined. In the Registrar-General's study of occupational mortality for England and Wales in the period 1930-32, "metal moulders and casters" and "iron foundry furnacemen and labourers" occupied fourth and fifth places in the list of occupations with a high mortality from lung cancer; the standardized death rates were respectively $93 \%$ and $88 \%$ above average (Registrar-General, 1938). In the succeeding analysis for the period 1949-53, the iron and steel worker still showed an increased mortality, but the excess was less marked (RegistrarGeneral, 1958); this, however, would be expected

TABLE 1

NATIONAL MORTALITY DATA FOR VARIOUS GROUPS OF FOUNDRY WORKERS, 1949-53*

\begin{tabular}{|c|c|c|c|}
\hline $\begin{array}{l}\text { Social } \\
\text { Class }\end{array}$ & Occupation & \begin{tabular}{|c|} 
No. of \\
Deaths at \\
Ages \\
20-64 Years \\
\end{tabular} & $\begin{array}{c}\text { Standardized } \\
\text { Mortality } \\
\text { Ratio }\end{array}$ \\
\hline $\begin{array}{l}\text { IIIc } \\
\text { IIIc }\end{array}$ & $\begin{array}{l}\text { Moulders and core-makers } \\
\text { Iron or steel } \\
\text { Non-ferrous }\end{array}$ & $\begin{array}{r}158 \\
28\end{array}$ & $\begin{array}{l}155 \\
122\end{array}$ \\
\hline $\begin{array}{l}\text { IVb } \\
\text { IIIc }\end{array}$ & $\begin{array}{l}\text { Foundry furnacemen } \\
\text { Iron or steel } \\
\text { Non-ferrous }\end{array}$ & $\begin{array}{l}17 \\
13\end{array}$ & $\begin{array}{l}142 \\
144\end{array}$ \\
\hline $\begin{array}{l}\text { IVb } \\
\text { IVb } \\
\text { IIIe }\end{array}$ & $\begin{array}{l}\text { Foundry labourers } \\
\text { Iron or steel } \\
\text { Non-ferrous } \\
\text { All skilled occupations, } \\
\text { other than in mining, } \\
\text { transport, or clerical } \\
\text { work or the Armed }\end{array}$ & $\begin{array}{r}136 \\
12\end{array}$ & $\begin{array}{r}131 \\
80\end{array}$ \\
\hline \multirow[t]{2}{*}{ IVb } & $\begin{array}{l}\text { Forces } \\
\text { All partly skilled occupa- }\end{array}$ & 13,038 & 99 \\
\hline & $\begin{array}{l}\text { tions, other than in agri- } \\
\text { culture }\end{array}$ & 4,452 & 99 \\
\hline
\end{tabular}

*Extracted from data published by the Registrar-General (1958). 
in view of the great increase in the general mortality from the disease. The data are summarized in Table 1. A similar excess has also been demonstrated in Scotland (Registrar-General for Scotland, 1956; Morrison, 1957).

Evidence of a different type has been obtained from the study of patients. In two large-scale studies in the U.S.A. Wynder and Graham (1951) and Breslow, Hoaglin, Rasmussen, and Abrams (1954) found that a higher proportion of men with lung cancer than of men with other diseases had been employed as "hot metal" workers-and the majority of these are likely to have worked with iron. A similar study in England, however, failed to confirm this finding (Doll and Hill, reported by Doll, 1953).

In sum, there is a considerable body of evidence to suggest that there is a specific industrial hazard from exposure to iron dust or fumes, with or without additional exposure to silica. None of it, however, is conclusive and at the present time the case must be regarded as not proven.

\section{Possible Risks}

Isopropyl Oil.-The only evidence to incriminate isopropyl oil comes from the U.S.A., where it was found that six among 75 men who were employed for more than five years on the manufacture of isopropyl oil died of respiratory cancer; four of these cancers arose in the nose, one in the larynx, and one in the lung (Weil, Smyth, and Nale, 1952). Nasal cancer is so rare that it is impossible to dismiss this finding as coincidence, but it remains to be seen whether there is a risk of any other respiratory cancer. In view of the association of lung and nasal cancer among the nickel workers, it would not be surprising if a lung cancer risk was also discovered.

Beryllium.-The possibility that men exposed to beryllium might develop lung cancer was first suggested in 1948 because of the appearance of sarcoidlike lesions in the lungs of beryllium workers and because bone tumours had been induced experimentally by the injection of beryllium into rabbits (Gardner and Heslington, 1946). Interest in the suggestion was enhanced when Vorwald (1955) found that it was possible to produce true bronchial carcinoma in rats by causing them to inhale beryllium. Only three cases of lung cancer have however, as yet been recorded among men who have been exposed to beryllium (Kahlau, 1954; Hardy, 1955), and it is quite possible that the association is coincidental. It is interesting to note that beryllium is the only non-radioactive substance with which it has as yet been possible to produce squamous cancer of the bronchi in animals.
Other Industries. - A high mortality from lung cancer has been recorded in certain areas of Montana, U.S.A., where the main industry is the

TABLE 2

LUNG CANCER MORTALITY IN FOUR COUNTIES OF MONTANA, U.S.A., 1947-48*

\begin{tabular}{l|l|c|c|c|c}
\hline \multicolumn{1}{c|}{ County } & Major Industry & \multicolumn{2}{|c|}{$\begin{array}{c}\text { Number of } \\
\text { Cases of } \\
\text { Lung Cancer }\end{array}$} & $\begin{array}{c}\text { Annual Death } \\
\text { Rate fron } \\
\text { Lung Cancer } \\
\text { per 100,000 }\end{array}$ \\
\cline { 2 - 6 } & M & F & M & F \\
\hline $\begin{array}{l}\text { Dear Lodge } \\
\text { Silver Bow } \\
\text { Cascade }\end{array}$ & $\begin{array}{l}\text { Copper smelting } \\
\text { Copper mining } \\
\text { Coper mining } \\
\text { and smelting } \\
\text { Gallatin }\end{array}$ & 21 & 0 & 146 & 0 \\
\hline
\end{tabular}

The crude death rate from lung cancer among white males in the U.S.A. in 1947 was 11 per 100,000 .

*After Lull and Wallach, cited by Hueper (1956).

mining and smelting of copper; the data are summarized in Table 2. The possibility that a carcinogenic substance occurs in association with copper ore is of particular interest in view of the fact that the nickel cancer risk in South Wales was apparently limited to the period when the nickel ore also contained large quantities of copper. It must be borne in mind, however, that many of the Montana mines are highly radioactive and radioactivity is also a possible explanation.

Ask-Upmark (1955) has suggested that there may be a risk from exposure to printing ink. He found an unexpectedly high proportion of printers among a small series of lung cancer patients in Sweden (eight out of 125) and demonstrated experimentally that printing ink was carcinogenic to the skin of mice.

Osburn (1957) has reported an unusual frequency of lung cancers among Africans in the Gwanda region of Southern Rhodesia and attributes this to a specific risk associated with the local mines. Between 1948 and 195622 cases of lung cancer was diagnosed among Africans; all were in men. Out of 36 cancers found at necropsy on African men, 14 arose in the bronchi, a very much higher proportion than has commonly been reported in Africa. Of the 22 men, 13 were employed in the mines when they were taken ill and six others are believed to have worked there at some time previously. One of the patients had worked at an asbestos mine, but the other mines at which the men had been employed were worked principally for gold; in some the ore contains a high proportion of arsenopyrite.

Industries of Interest because of Absence of Risk

Two groups of industries are of particular interest because the evidence suggests that there is no 
substantial risk of lung cancer among their employees, although there are theoretical reasons for thinking that there might have been. The first of these includes all those industries in which the employees have a special exposure to the fumes of petrol or diesel-driven engines. These fumes may contain measurable quantities of 3:4-benzpyrene and other carcinogenic polycyclic hydrocarbons and it has been thought that they may contribute to the excess mortality from lung cancer among the residents of large towns. Kennaway and Kennaway (1947) selected a group of outdoor occupations and found that the mortality from lung cancer among them was slightly higher than average. Similar results were obtained for a later period by the Registrar General (1958). The data are summarized in Table 3.

TABLE 3

MORTALITY FROM LUNG CANCER IN ENGLAND AND WALES IN CERTAIN OCCUPATIONS SPECIALLY EXPOSED TO ROAD DUST AND VEHICLE FUMES

\begin{tabular}{|c|c|c|c|}
\hline \multirow{3}{*}{ Occupation } & \multicolumn{3}{|c|}{ Standardized Mortality Ratio } \\
\hline & \multicolumn{2}{|c|}{$\begin{array}{c}\text { Kennaway and } \\
\text { Kennaway } \\
\text { (1947) }\end{array}$} & \multirow{2}{*}{$\begin{array}{c}\begin{array}{c}\text { Registrar- } \\
\text { General } \\
(1958)\end{array} \\
1949-53 \\
\end{array}$} \\
\hline & $1921-32$ & 1933-38 & \\
\hline \multirow{3}{*}{$\begin{array}{l}\text { Paviours, street masons, con- } \\
\text { cretors, and asphalters } \\
\text { Council labourers, road } \\
\text { sweepers, and dustmen } \\
\text { Drivers of horse-drawn vehicles } \\
\text { Motor drivers (goods and pas- } \\
\text { sengers) }\end{array}$} & 209 & 137 & 135 \\
\hline & $\begin{array}{l}173 \\
144\end{array}$ & $\begin{array}{l}167 \\
131\end{array}$ & $\overline{222}$ \\
\hline & 142 & 153 & 118 \\
\hline
\end{tabular}

In contrast, retrospective studies of the occupational histories of patients with lung cancer have provided no evidence of a disproportionate number of patients employed in this type of occupation (Wynder and Graham, 1951; Doll, 1953; Breslow et al., 1954). The clearest evidence, however, comes from the experience of the London Transport Executive. In an analysis of the mortality amongst the various groups of employees, Raffle (1957) found (1) that the total mortality from lung cancer was somewhat lower than that for men of the same age in London generally, and (2) that the mortality among bus drivers and conductors and the engineering staff at bus garages was lower than that observed among underground railway workers and the engineering staff at trolley bus depots. These results suggest that the fumes of petrol-driven motors are unlikely to be a major cause of the disease; but they are not of great significance in relation to diesel engines, as these have not been on the road in large enough numbers long enough for diesel fumes to be expected to have produced any evidence of cancer - even if they were capable of doing so.
The second group of industries consists of those with a hazard of silicosis. Data collected by the Miners' Phthisis Medical Bureau (1936) in Witwatersrand showed that in over 3,000 necropsies on European miners the prevalence of lung cancer was the same, irrespective of the presence of silicosis; moreover it was practically the same as that found at the General Hospital, Johannesburg, among men who had never worked underground. In South Wales, James (1955) found that the prevalence of lung cancer at necropsy was, at each age, less among coal-miners than among non-miners from the same area and that the prevalence fell as the degree of pneumoconiosis increased. Some degree of pneumoconiosis is present in most forms of industrial lung cancer, but all investigators agree that there is no quantitative relationship between silicosis and the presence of the cancer. It must be concluded that where there is an industrial hazard of lung cancer it is due to some specific characteristic of the industry and not to a non-specific effect of pneumoconiosis.

\section{Contribution of Industrial Studies to the Understanding of Carcinogenesis in General}

Site Specificity.-In all the industries in which a specific risk of lung cancer has been recognized, the risk has been confined to the lungs or, at the most, to the lungs and to one other site. In one industry (the refining of nickel) there has also been an important risk of nasal cancer and it is possible that there may be a risk of nasal cancer associated with the chromate industry. A few cases have been recorded among chromate workers by Baetjer (1950) and this disease is normally so rare that the occurrence of even two or three cases is suggestive. In no industry is there any evidence to suggest that a risk of lung cancer is accompanied by a risk of laryngeal cancer. It is clear, therefore, that agents which are capable of producing cancer in the bronchi, and which presumably reach the bronchi via the upper respiratory passages, do not necessarily affect the mucosa of the upper parts of the respiratory tract; in fact, they generally do not. This may, perhaps, be explained by variation in the susceptibility of the tissues to the particular agents, but so little is known about the physical properties of the various dusts and gases involved that the true explanation may be much simpler and the differences may depend on quantitative differences in the amounts of the carcinogen deposited.

In two industries (the production of gas and the manufacture of certain arsenical compounds) there is also known to have been an increase in the incidence of cancer of the skin. In both these, there is a clear reason for the selection of this site: in the 
gas industry the skin may be heavily contaminated with coal-tar and, in the case of exposure to arsenic, the skin serves as the organ of excretion. No other type of cancer is known to have increased in any of the industries which have been studied and it is reasonable to conclude that the production of lung cancer is the result of a local reaction rather than of a general metabolic disturbance.

Cramer's Hypothesis.-In 1934, Cramer suggested that the susceptibility to cancer might be determined by intrinsic (possibly genetic) factors and that the effect of environmental agents might be to determine the site at which the predestined cancer would eventually appear. The suggestion was put forward tentatively to account for the fact that the crude death rates from cancer were similar in the two sexes and in several different countries, while the distributions of the primary sites were grossly different. A more detailed examination of the mortality rates, taking into account the differences in the age distribution of the populations, makes this hypothesis less attractive than it originally appeared. Nevertheless, it has continued to influence medical thought and it is worth noting that the data obtained from industrial studies weigh heavily against it. If the hypothesis were true, it would be expected that an increased incidence of lung cancer among men in a particular occupation would be associated with a diminished incidence of cancer in other sites. The results of several studies demonstrate that this is, in fact, not so. Sufficiently detailed data are not available for the miners of Schneeberg and Jachymov, but in all the other industries in which a specific risk of lung cancer has been established, it has been shown that the mortality from other types of cancer has been undiminished (Hill, 1939; Machle and Gregorius, 1948; Doll, 1952, 1955, 1958; Bidstrup and Case, 1956).

Latent Period.-In all types of industrial cancer there has been a long interval between the year of first employment in the industry and the appearance of the cancer. Lung cancer is no exception. The latent period has been most commonly of the order of 15 to 30 years, but some few growths have appeared less than five years after first employment and others as long as $\mathbf{4 0}$ or $\mathbf{5 0}$ years afterwards. The occurrence of some of the growths with a very short latent period may be coincidental, but it is impossible to set precise limits to the possible durations which may be observed. Whether the risk of occurrence of an industrial cancer decreases after a certain length of exposure is uncertain. The reduction in the number of cases with the longer latent periods is a necessary result of the reduction in the number of men alive in the older age groups and the apparent reduction is often exaggerated by the failure to trace all the cases which occur among men who leave the industry. Cases are known to occur many years after all exposure has ceased, but there are as yet no data which would enable an estimate to be made of the reduction in risk which follows the cessation of exposure. It is, in fact, not yet known whether the removal of the hazard has any significant effect on the size of the risk once there has been a prolonged exposure. Knowledge of the relationships between risk and duration of exposure would be of great importance to the understanding of the mechanism of carcinogenesis. One of the most practical ways of obtaining this information would be by a detailed study of the risk among cohorts of employees who continue to be employed in a hazardous industry and among those who cease employment after various periods.

Variety of Carcinogens.-Animal experiments have shown that a great variety of substances are capable of carcinogenic activity. This knowledge has been reinforced by the finding that exposure to many different industrial substances is capable of producing cancer in man. In the case of lung cancer, the range is particularly wide-radioactive substances, polycyclic hydrocarbons, asbestos, and simple inorganic compounds of arsenic, chromium, and nickel (possibly even the elements themselves). The discovery of a large risk in relation to some of these simple substances is surprising and it may be expected that a more exact definition of the conditions under which they can cause cancer will lead to an important increase in our knowledge of the mechanism of carcinogenesis generally.

\section{Conclusion}

The history of industrial lung cancer has shown that a specific industrial hazard may be overlooked for many years by both management and employees. The first indication of a risk has usually been an acute medical observation that a disproportionate number of the patients presenting with lung cancer have been employed in a particular industry; alternatively evidence has been provided by the occupational mortality statistics for the whole country or by an analysis of the occupations recorded on the death certificates in the locality in which the industry was situated. Sometimes this evidence has been overwhelming, as in the case of the Schneeberg miners; but usually, to obtain proof of the existence of a risk, it has been necessary to carry out a detailed study of the fate of selected workers over a number of years and to compare the mortality among them with that recorded for other 
populations. Lung cancer is a rapidly fatal disease and although it is now a common cause of death, its prevalence is so low that, even in the presence of a major risk, the examination of as many as 1,000 workers may fail to reveal any cases at all on a single occasion.

In recent years the mortality from lung cancer due to non-industrial causes has increased enormously; now in Britain lung cancer accounts for more than $10 \%$ of all deaths among men aged from 45 to 64 years, the ages at which a risk of industrial cancer may most readily be detected. In these circumstances, the discovery of a new risk by simple clinical observation is difficult and if any additional risks remain to be discovered it is probable that they will be revealed by planned prospective studies, undertaken with the special object of finding out whether any risks exist. That all the existing risks have been discovered seems most unlikely. Moreover, new materials and new processes are being introduced into industry almost daily and there is no reason to suppose that they will necessarily all be free from risk. It may be expected that industrial studies will continue, as in the past, to make important advances in our knowledge of all aspects of carcinogenesis. In this respect, detailed studies of the relationship between exposure, incidence, and duration of latent period may be of particular value.

\section{REFERENCES}

Alwens, W., Bauke, E. E., and Jonas, W. (1936). Arch. Gewerbepath. Gewerbehyg., 7, 69.

Amor, A. J. (1939). Bericht über den VIII internationalen Kongress für Unfallmedizin und Berufskrankheiten, Frankfurt on Main, September 1938, Vol. 2, p. 941 . Thieme, Leipzig.

Ask-Upmark, E. (1955). Dis. Chest, 27, 427.

Baetjer, A. M. (1950). A.M.A. Arch. industr. Hyg., 2, 487 and 505.

Bale, W. F., and Shapiro, J. (1955). Paper $\mathbf{P} / 76$, Vol. 13, Proceedings of the International Conference on the Peaceful Uses of ings of the International Con

Attomic Energy. Geneva.
Bidstrup, P. L., and Case, R. A. M. (1956). Brit. J. industr. Med., $13,260$.

Bohlig, H., and Jacob, G. (1958). Proc. 12th Internat. Congress on Öccupational Health, Helsinki, 1957 Vol. 3. p. 308.

Braun, D. C., and Truan, T. D. (1958). A.M.A. Arch. industr. Hlith, 17, 634 .

Breslow, L., Hoaglin, L., Rasmussen, G., and Abrams, H. K. (1954). Amer. J. publ. Hith, 44, 171 .

Bridge, J. C. (1941). In Annual Report of the Chief Inspector of Factories for the Year 1939, p. 22. H.M.S.O., London.

Brinton, H. P., Frasier, E. S., and Koven, A. L. (1952). Publ. Hlth Rep. (Wash.), 67, 835.

Burrows, H., and Clarkson, J. R. (1943). Brit. J. Radiol., n.s., 16,

Cember, H. (1958). Paper 15/P/900. Proceedings of the Second International Conference on the Peaceful Uses of Atomic Energy. Geneva.
Cramer, W. (1934). Lancet, 1, 1.

Doll, R. (1952). Brit. J. industr. Med., 9, 180.

- (1953). Brit. med.J., 2, 521 and 585.

- (1955). Brit. J. industr. Med., 12, 81.

- (1958). Ibid., 15, 217.

Evans, R. D., and Goodman, C. (1940). J. industr. Hyg., 22, 89.

Faulds, J. S., and Stewart, M. J. (1956). J. Path. Bact., 72, 353.

Gardner, L.'U., and Heslington, H. F. (1946). Fed. Proc., 5, 221.

Gloyne, S. R. (1951). Lancet, 1, 810.

Glucksmann, A., Lamerton, L. F., and Mayneord, W. V. (1957) In Cancer, Vol. 1, p. 497, ed. R. W. Raven. Butterworth, London.

Goldblatt, M. W. (1958). Brit. med. Bull., 14, 136

- and Goldblatt, J. (1956). In Industrial Medicine and Hygiene, Vol. 3, p. 209, ed. E. R. A. Merewether. Butterworth, London.

Gross, E., and Kölsch, F. (1943). Arch. Gewerbepath. Gewerbehyg.,

Hardy, H. L. (1955). A.M.A. Arch. industr. Hlth, 11, 273.

Hill, A. B. (1939). Report to Mond Nickel Company, quoted by Morgan (1958).

$\overrightarrow{\text { Holat }}$, and Faning, E. L. (1948). Brit. J. industr. Med., 5, 1.

Hueper, W. C. (1955). J. nat. Cancer Inst., 16, 55.

(1956. Public Health Monograph, No. 36. (Wash. Public Health Service Publication, No. 452.)

(1957). Proceedings of the 7th Saranac Symposium on Pneumoconiosis.

- (1958a) A.M.A. Arch. Path., 65, 600

- (1958b). A.M.A. Arch. industr. Hlth, 18, 284

James, W. R. L. (1955). Brit. J. industr. Med., 12, 87

Kahlau, G. (1954). Ergebn. allg. Path. path. Anat., 37, 258

Kawahata, K. (1938). Gann, 32, 367.

Kaw. (1936). J. Hyg. (Camb.), 36, 236.

Kennaway, E. L., and Kennaway, N. M. (1947). Brit. J. Cancer, 1, 260

Kuroda, S. (1937). Industr. Med., 6, 304

- and Kawahata, K. (1936) Z. Krebsforsch, 45, 36

Lisco, H. and Finkel, M. P. (1949). Fed. Proc. 8, 360

Løken, A. C. (1950). T. norske Laegeforen., 70, 376.
Lorenz, E. (1944). J. Nat. Cancer Inst. 5 , i.

Lorenz, E. (1944). J. Nat. Cancer Inst., 5, 1.

Lynch, K. M., and Smith, W. A. (1935). Amer. J. Cancer, 24, 56.
Machle, W., and Gregorius, F. (1948). Publ. Hlth Rep. (Wash.), 63, 1114 .

Mancuso, T. F., and Hueper, W. C. (1951). Industr. Med., 20, 358.

Merewether, E. R. A. (1944). In Annual Report of the Chief
Inspector of Factories for the Year 1943, p. 45. H.M.S.O. Inspecto

(1949). In Annual Report of the Chief Inspector of Factories
(n) for the Year 1947, p. 45. H.M.S.O., London.

Miners' Phthisis Medical Bureau (1936). Report for the Three Years ended July 31, 1935. Union of South Africa Govt. Printer, Pretoria.

Morgan, J. G. (1958). Brit. J. industr. Med., 15, 224.

Morrison, S. L. (1957). Ibid., 14, 130.

Osburn, H. S. (1957). Cent. Afr. J. Med., 3, 215.

Perry, K., Bowler, R. G., Buckell, H. M., Druett, H. A., and Schilling, R. S. F. (1948). Brit. J. industr. Med., 5, 6.

Pfeil, E. (1935). Dtsch. med. Wschr., 61, 1197.

Raffle, P. A. B. (1957). Brit. J. industr. Med., 14, 73.

Registrar-General (1938). Decennial Supplement, England and Wales, 1931. Part IIA. Occupational Mortality [1930-32]. Wales, 1931. Part

H.M.S.O., London.
(1958). Decennial Supplement, England and Wales, 1951. Occupational Mortality, Part II. H.M.S.O., London.

Registrar-General for Scotland (1956). Annual Report 1955, No. 101, Appendix IX, p. 75. H.M.S.O., Edinburgh.

Reid, D. D., and Buck, C. (1956). Brit. J. industr. Med., 13, 265.

Schinz., H. R., and Uehlinger, E. (1942). Z. Krebsforsch., 52, 425.

Sikl, H. (1950). Acta Un. int. Cancr., 6, 1366.

Turner H. M. and Grace, H. G. (1938). J. Hyg. (Camb.), 38, 90

Uhlig, M. (1921). Virchows Arch. path. Anat., 230, 76.

Vorwald, A. J. (1955). Lecture to the Harvard School of Public

Health, Boston.

Weil, C. S., Smyth, H. F.,

Wynder, E. L., and Graham, E. A. (1951). Ibid., 4, 221. 